\title{
Social Behavior of Women Migrant Workers from Taiwan and Hong Kong After Returning to Their Home Regions
} (Case Study of Pagu Village, Wates District, Kaediri Regency, Indonesia)

\author{
Junari $^{1}$, Tauchid Noor ${ }^{2}$ and Catur Wahyudi ${ }^{3}$ \\ ${ }^{1}$ Doctor of Social Sciences Doctoral Program \\ ${ }^{1-3}$ University of Merdeka Malang \\ Indonesia
}

\begin{abstract}
At Present cannot be denied that at this time women who work outside the home have reached their peak with the discovery of promising employment fields from an economic perspective, namely as Women Migrant Workers Overseas. As happened in Wates sub-district, the reasons for women or wives choosing to work as women migrant workers abroad are from an economic background that is still not fulfilled, the high level of daily needs, education costs and children's health, while the income of their husbands which is still very low. Becoming Women Migrant Workers Overseas is considered as the answer to get a better economic status. The purpose of this study is to describe and analyze the social behavior and images exhibited by female migrant workers from Taiwan and Hong Kong after retiring and returning to their place of origin, and to describe and analyze internal and external factors that encourage social behavior exhibited by female migrant workers from Taiwan and Hong Kong after retiring and returning to their home regions. To uncover this reality, qualitative research methods are used where the data obtained is processed by organizing and sorting data into patterns or categories and describing basic units so that they are more readable and interpretable. Based on the facts and phenomena obtained in the field, the results of the study are as follows: First, Female Migrant Workers from Taiwan and Hong Kong after retirement and returning to their area of origin become more consumptive due to different expectations and realities after following lifestyle trends by no longer basing on the value of the goods they consume. Second, the Changing Behavior of Social Life of Migrant Workers Women from Taiwan and Hong Kong after retiring and returning to their hometown due to environmental factors, adaptation to the work environment, length of service and lack of communication. Third, the Community Perception of the Success of Women Migrant Workers from Taiwan and Hong Kong after retiring and returning to their hometowns is a hegemony that makes the Migrant Workers follow that perception. Internal and external factors that encourage social behavior exhibited by female migrant workers from Taiwan and Hong Kong after retiring and returning to their home areas internally include: motivation of women migrant workers working abroad to fulfill their needs, following in the footsteps of successful female migrant workers previously and the lack of employment opportunities in the country, and the perception of being a female migrant worker abroad brought changes in the economic upturn and appreciation from the community. External factors include, reference groups originating from female migrant worker friends tend to be influenced by technological advances and Western style, improving family life and encouraging other family members to become successful female migrant workers is the goal of women becoming female migrant workers abroad, working in Foreign Affairs is considered to be able to improve social class and dignity of self and their families better. From these findings, a Major Proposition for Changing Social Behavior of Former Women Workers can be drawn from a change in consumption behavior that tends not to base the value of the goods consumed and social life behavior caused by environmental factors, adaptation to the work environment, length of work and rarely communicate.
\end{abstract}

Keywords: Social Behavior, Female Migrant Workers.

\section{INTRODUCTION}

Job seekers is increasing from time to time while the jobs available is less, so that the number of unemployed in Indonesia is growing. To find a job has been very difficult. The steps taken to reduce the number of unemployed increasing government opened an opportunity for its citizens to work abroad, hereinafter referred to as the Migrant Workers, namely 
Indonesian citizens, both men and women who carry out activities in the field of economic, social, scientific, professional sports as well as follow PRAKTIKA abroad by land, sea and air in a certain period under employment agreements (Regulation of the Minister of Manpower No. 02 / Men / 1999).

Since the information on employment opportunities abroad with a big salary dibangdingkan with in the country and those who have succeeded after working abroad, many people from rural communities interested in becoming migrant workers be it male or female, either already married or not married. Similarly, in the rural communities in the region, especially in the district of Kediri, Wates, most people, especially women choose to become a Women Migrant Workers abroad. Countries are often used as the destination of their work is a state of Malaysia, Saudi Arabia, Hong Kong, Taiwan and Korea. They were forced to leave their families in order to make a living and a better life improve enough clothing, food, housing perhaps even more than that.

However, the adverse effects or negative side of a change or an increase in life whether it is a change in the economic field as well as in the field of social after becoming Migrant Women is the behavior of consumptive life Migrant Workers Women have become a sort of uncontrollable caused by an increase in revenue or earnings this is increasing as well consumptive lifestyle many migrant workers upon their return to their villages.

\section{LITERATURE REVIEW}

\subsection{Social Behavior}

Social behavior is an atmosphere of mutual dependence which is a must to ensure the existence of man (Ibrahim) [1]. As evidence that humans in fulfilling the necessities of life as a private self can not do it alone but requires the help of others. There bond of interdependence between one person and another. This means that the survival of mankind took place in an atmosphere of mutual support in togetherness. For the man demanded to be able to work together, respect each other, do not interfere with the rights of others, intolerant in social life .. According to Krech, Crutchfield and Ballachey (1982) in Rusli Ibrahim, the social behavior of a person that appears in response patterns between people expressed by the reciprocal relationship between individuals [1].

\subsection{Lifestyle}

Lifestyle according to Kotler is the lifestyle of a person in the world who iekspresikan in activities, interests, and his opinions. Lifestyle described the "whole person" in interacting with the environment [2]. According Mowen and Minor, the lifestyle is to show how people live, how to spend the money, and how to allocate time [3]. In addition, lifestyle according to Kotler and Armstrong (in Rianto) is a pattern of life in the world of everyday life that is expressed in activities, interests and opinions are concerned [4].

\subsection{Social Transformation}

Social change is defined as the changes regarding social structures and social institutions. Social change is not only related to the wide scope of the changes, but also related to other dimensions such as rhythm, the magnitude of the effect, or deliberate in the process of change (Rahardjo) [5]. Stzompka said that social change can be understood as changes that occur within or include a social system. More precisely there are differences between certain system states in different time periods. While Mac Iver said that social change is a change that occurs in social relations or changes in the balance (equilibrium) social relations.

\subsection{Social Interaction}

Soekanto gives the sense of interaction (interaction) is a reciprocal relationship between certain parties [6]. While understanding social word is in respect of inter-personal actors or related to social processes. So the social interaction is a dynamic interrelationship between individuals (interpersonal), between groups of people and between people individually with the group. In other words, implies social interaction as a process in which people communicate with each other influence both in terms of feelings, thoughts and actions. Social interaction is one of the very basic things in life. Because social interaction is the basis of social processes. Social processes are ways of relating that can be seen when individuals and groups of people to meet each other and determine the system and forms of the relationship. Social processes is defined as the reciprocal influence between different art of living together. Social interaction begins when two people meet and then admonish, shake hands and then spoke at length. Social interaction also occurs when a protocol in an event greetings to all attendees. shake hands and then spoke at length. Social interaction also occurs when a protocol in an event greetings to all attendees. shake hands and then spoke at length. Social interaction also occurs when a protocol in an event greetings to all attendees.

\subsection{Structural Functional}

Wirawan, Structural Functional Theory discusses human behavior in the context of the organization (community) and how these behaviors are in (to maintain) the conditions equilibirium [7]. How do people maintain the functions of sub-systems in social interactions and changes. In maintaining that balance is inevitable disturbances (restriction), both of which come from within (internal) or outside (external). If a challenge to the direction of the imbalance is so great and sub-systems were overwhelmed to deal with it, the efforts of the system is to avoid a split structure. Specifically, Parsons conceptualizing an ideal society in which cultural values institutionalized in social systems and norms are internalized in the personality system. Then, according to this view individuals will obey social expectations-expectations as regards the regulation is valid (considering the source) and because the regulations consistent with their own values are internalized it. As well as resulting 
from the orientation of shared values, norms have aligned characters, so the competing expectations will not plunge the individual into the inner conflict. The individual is the main function in the social (Ritzer \& Smart) thus competing expectations will not plunge the individual into the inner conflict [8]. The individual is the main function in the social (Ritzer \& Smart) thus competing expectations will not plunge the individual into the inner conflict. The individual is the main function in the social [8].

\subsection{Motivation}

Griffin, states that motivation is a set of factors that cause people to behave in a certain way [9]. In a more general sense Hoy and Miskel says that motivation refers to the process of making choices among various forms of voluntary activities of a person [10]. According to Robbins (2002) explained that the motivation is the driving force of the human self and conscious effort to mobilize, direct and coordinate and maintain the person's behavior [11].

\section{RESEARCH METHODS}

\subsection{Approach and Strategy Research}

The approach is the treatment of the object as a standpoint of ethics or otherwise as viewpoint EMIC [12]. In a qualitative approach, there are several forms of research are different from each other in the direction, goals, interests, and the final result. The forms of qualitative research is also called qualitative research models [13]

\subsection{Research Focus}

1. Social Behavior change shown by former Women Migrant Workers From Country Taiwan and Hong Kong who has been Full Employment indicators:
a) consumption behavior
b) Life behavior
c) Due Changes Public Perception

2. internal and external factors that encourage Social Behavior change shown by Women Migrant Workers From Taiwan and Hong Kong, which has been Full Employment with indicators:

a) Internally, in the form of motivation and perception former Women Migrant Workers

b) Externally, the form reference groups, family, and social class

\subsection{Data Analysis Techniques} [12]:

Mc Drury (Colaborative Group Analysis of Date, 1999) as quoted Moleong phases of qualitative data analysis as follows

1. Reading / studying data, mark key words and ideas that exist in the data.

2. Learn the key words, try to find themes that are derived from data

3. Write down a model that is found;

4. Coding has been done.

\section{DISCUSSION}

\subsection{Social Behavior exhibited by Migrant Women Workers from Taiwan and Hong Kong after the after-work and return to their home area}

Social Behavior of Female Migrant Workers from Taiwan and Hong Kong after the after-work in the village Capping, based on observations and interviews known that their main goal is to work abroad for family economic needs, to be increased. In addition to excuse lack of jobs in Indonesia. The phenomenon shows that migrant women who work abroad, after the completion of the employment contract they return to their home area Indonesia with sufficient capital or not, usually when they came back with the money is not enough to venture capital, they will again become migrant workers woman, after her money enough to capital, they will open the desired effort. However, not all women migrant workers are thinking of getting venture capital,

Shifting the main purpose of women migrant workers resulted from changes in the behavior of women migrant workers to satisfy the consumer towards personal pleasure because he felt he was able to purchase the desired items. This is in accordance with the opinion Anggasari (in Sumartono) says consumer behavior is a behavior to buy goods unplanned or not taken into account so that nature becomes excessive [14]. 


\subsubsection{Consumption Behavior}

Changes in consumer behavior Migrant Women from Taiwan and Hong Kong after the after-work and return to their home area or Culture of Consumerism is an understanding that serve as a lifestyle which considers luxury goods as a measure of happiness, pleasure and self-gratification, the culture of consumerism can be regarded as examples of frugal lifestyle. If the culture of consumerism has become a lifestyle, it will give rise to a need that can never be satisfied by what is consumed and keeps people consume. Today many of the some even all walks of life have not been able to prioritize the items that must be met by mere desire. Migrant women is one that experienced the culture of consumerism. As already described in changes in lifestyle patterns Migrant Women Workers from Taiwan and Hong Kong after the after-work and return to their hometown, the culture of consumerism that hit Migrant Women Workers of them is their consumption behavior towards gadgets and fashion. Unconsciously, humans will continue to have a need to be met, always within the limits of less and less, and never get enough of what they have today. The requirement of which is the daily food, fashion, transportation, technology, housing and so forth. Unconsciously, humans will continue to have a need to be met, always within the limits of less and less, and never get enough of what they have today. The requirement of which is the daily food, fashion, transportation, technology, housing and so forth. Unconsciously, humans will continue to have a need to be met, always within the limits of less and less, and never get enough of what they have today. The requirement of which is the daily food, fashion, transportation, technology, housing and so forth.

Consumerism show on a person's lifestyle with an incredible desire to meet the needs of excessive consumption. The phenomenon that frequently arises is the fulfillment of desire without considering the consequences that accompany it, especially the relationship with its economic potential. Consumerism concept becomes important is delivered to observe the lifestyle of Female Migrant Workers from Taiwan and Hong Kong after the after-work and return to their home area which is quite consumptive when abroad. These symptoms arise one of them caused by imaging and social status. A significant shift in society in consuming goods, namely: the value to be the value of the image. Purchased goods are not seen from the aspect of usefulness, but of status.

Of consumer behavior conducted by the Women Migrant Workers from Taiwan and Hong Kong after the after-work and return to their home area is influenced by many factors both from within and outside himself. Some kind of consumer behavior is mostly done by the Women Migrant Workers from Taiwan and Hong Kong after the after-work and return to their hometown, the first is the consumer in the purchase of electronic goods and motor vehicles. Facts on the ground indicate something else, Hp not only as a communication tool but also as a symbol of prestige. Hp purchased not because the original usefulness of the means of communication, but rather the "tools" for the existence of self. The fact or facts in this field strengthens the assumption that people have been trapped in a system of signs, they are no longer able to distinguish between real and imaginary. Therefore, it can be said that the current consumption is performed Migrants Women from Taiwan and Hong Kong after the after-work and return to their home villages not only fulfill their desires for their needs. Furthermore, both the consumption of cosmetics or anything to alter their physical appearance. Lots of money they transform and change the appearance like changing hair style, buy expensive clothes and cosmetics that do not consume adjusted to income. Behavior that does not see the real state of his life is a form of hyper reality, because it makes the secondary needs as if the primary requirement. Moreover, he was not able to see the reality of life that are in economic conditions "less". Third,

Changes in consumer behavior tend to come from abroad as a result is in line with that put forward Raharjo, where each community during the life changing [5]. There are changes that influence is limited and spacious, and there are also changes the effect of the slow but there is also a quick walk. This change will only be determined by a person who was researching the structure and life of a community at a time and compare it with the composition and the community life sometime in the past.

The results also showed that the result of consumerism behavior of female migrant workers from Taiwan and Hong Kong after retiring and returning to their area of origin was constructed through the influence of the modern environment in which they worked about an item so that female migrant workers from Taiwan and Hong Kong after work and returned to their home regions will continue to be influenced by the culture of consumerism. If the thought has been affected, then whatever the price will be paid without regard to the value of the use or importance of the item to them. This is in line with Engel el al [15] and Mowen [16] lifestyle is a lifestyle that involves how people use time and money. Lifestyle can also be defined as a frame of reference or a person's frame of reference used in the act, where the individual is trying to make all aspects of life related in a certain pattern, and strategizes how he wants to be perceived by others.

Firstly simple lifestyle changes into a lifestyle that tends to follow the trend among Women Migrant Workers from Taiwan and Hong Kong after the after-work and return to their home area, Lifestyle changes that include clothing, housing, and food. Clothing is everything in life from the head to the toe as clothing, electronic appliances, and gadgets. While the board that everything feels a need Women Migrant Workers from Taiwan and Hong Kong after the after-work and return to their home area like new home with models that present, or housing. And the last is food that includes a taste to eating habits. The increasing number of human needs, the demands also an increase in lifestyle. Lifestyle is the hallmark of a modern world, or commonly also called modernity [17]. Lifestyle is intimately associated with the changing times and technology. The increasing age and the increasing sophistication of technology, the increasingly widespread adoption of lifestyle anyway by humans in everyday life. Lifestyle can give a positive or negative influence on those who run it, depending on how a person lives a healthy lifestyle. The pattern of life that is worrisome is the consumptive lifestyle that leaves a productive lifestyle. 


\subsubsection{Life Behavior}

Changes in behavior is not a mere expression of class and prestige, but it is a marking system, which communicates the identity and cultural differences. Youth subcultures communicate their distinct identity and their differences from and in opposition to peers, parents, and the dominant culture through a political force [18]. In short, it is a lifestyle Migrant Women from Taiwan and Hong Kong after the after-work and return to their home villages here are adaptations active experienced Migrant Women from Taiwan and Hong Kong after the after-work and return to the place of origin of the change that took place in the vicinity in order to meet the need to come together and socialize with others. Theoretically lifestyle includes a set of habits,

The phenomenon of migrant women show life before and after becoming migrant women is certainly different. Differences environment is one of the contributing factors. The area of origin of migrant workers are predominantly women from the countryside, where the village community itself is still strong values and social norms in the society, and also not many outside influences. Migrant women after returning home tend to experience changes in behavior. Different environments and different relationships also influence behavioral change. This is in line with the theory of voluntaristic Prasons where there are three aspects of human action that is the agent unit (perpetrator) is trying to realize its objectives in a situation when the material conditions and the way a manner that allows use to realize the goals.

The environmental employment of women migrant workers abroad has a significant influence on the behavior of female migrant workers in interactions with others. The employer's family environment can also affect the behavior of Migrant Workers Workers from Taiwan and Hong Kong after the after-work and return to their home area the pattern of life. In addition to environmental factors also affect the life of friendship migrant women abroad. After returning to their hometown, women migrant workers bring life habits from abroad. It is encouraging peers and others of the homelands to work abroad. With the motivation to earn a high income and be able to follow contemporary trends like other friends. The number of women migrant workers who go there is the formation of a friendship group of women migrant workers abroad as a means to connect fraternity. Friendship groups of women migrant workers can affect the behavior of female migrant workers, both positive and negative directions in the association.

The above is also in line with states Style is not merely an expression of class and prestige, but it is a marking system, which communicates the identity and cultural differences [18]. Youth subcultures communicate their distinct identity and their differences from and in opposition to peers, parents, and the dominant culture through a political force. In short, it is a lifestyle Migrant Women from Taiwan and Hong Kong after the after-work and return to their home villages here are adaptations active experienced by migrant women to the changes taking place around it in order to meet the need for unified and socialize with others. Theoretically lifestyle includes a set of habits, views and patterns of response to life, and especially equipped to live

The results also showed those who become migrant women from Kediri is the village, said the village as far from the hustle of the city, the area is somewhat isolated and to find employment in their own place is a bit hard. Rural community lifestyle also influenced by the geographical mobility such as urbanization, immigration. Geographic mobility in question is a condition in which a person has lived outside his residence. Geographic mobility of a person to the city, for example, can affect the lifestyle because the city is considered to be a place that allows someone who is in contact with him to get the expansion or addition of a wide range of experiences and new knowledge. This corresponds to the reality that the city has a cultural diversity that can be emulated by the village [19].

The factor environment is a strong influence in the change undergone Female Migrant Workers from Taiwan and Hong Kong after the after-work and return to their hometown, the changes experienced include dressing tastes change, and also how their association. Thousands of migrant workers changing westernized culture, which leads to moral decline. The needs are psychological, psychological support, social norms and cultural values of each can control human action.

This above is in line with the theory of stylistic shift Parson live according according to Ritzer and Goodman, which states "the cultural system at the peak of the action system, which he calls the cultural determinists [8]. Cultural system is the main force that binds the various elements of the social world. Culture is a binding force action system, mediates the interaction between actors, encounters personality, and unify the social system. The culture has a special capacity to be a component of other systems. In the social system, the system embodied in the norms and values, and personality in the system's norms and values are internalized by the actor. Despite the cultural system be part of a system of action, but the cultural system can have its own separate existence of a system of measures, namely in the form of knowledge, symbols, and ideas.

Sistem personality in Parson action system is controlled by the social system and the cultural system, because the system of personality is the result of socialization and internalization of the social system and the cultural system. However, it does not mean that the personality system is not free at all, personality becomes an independent system through its relationship with the organism itself and through his own unique experience.

Behavior Change Social Life Migrant Women from Taiwan and Hong Kong after the after-work and return to their home area caused by environmental factors, the adjustment to the work environment, long working life and lack of communication in line with the opinions Krech, Crutchfield and Ballachey in Rusli Ibrahim, a person's social behavior was evident in patterns of response among those represented by the interrelationships between individuals [1]. Social behavior is also identical to the person's reaction to others (Baron \& Byrne in Rusli Ibrahim) [1]. The behavior is indicated by feelings, actions, attitudes, beliefs, memories, or respect for others. 


\subsubsection{Due Changes Public Perception}

Yan Women Migrant Workers work abroad assume that he has a lot of money as a measure of success, it is measured by how you spend earned money to buy luxury -Items and change the physical appearance that does not correspond to revenue, making the secondary needs as a primary need. The behavior of women migrant workers mentioned above only meets the needs apparent, consequently making himself trapped in a life of hedonism, whereas the public perception is negative it actually considers the behavior of female migrant workers is not in accordance with the norms in society.

In general, there are three factors that influence behavior change Female Migrant Workers from Taiwan and Hong Kong after the after-work and return to their home area. First, the public perception of women migrant workers themselves, that turns people always assume Migrant Women from Taiwan and Hong Kong after the after-work and return to their home area has a lot of money. Moreover, the notion that measures the success of something is visible that is owned by the Women Migrant Workers from Taiwan and Hong Kong after the after-work and return to their home area. Indirectly, it affects the behavior of female migrant workers in spending money on their works. The goods they buy also have a symbolic value, which can show their success working abroad. If it is so then it is clear that the meaning of the commodities they buy is more important than the commodities themselves. For example, the new motor that has a symbolic value for the village community in general, because buying a new motorbike with cash is only done by people who are considered capable. Therefore, it is not surprising that many of the Migrant Women Workers from Taiwan and Hong Kong after the after-work and return to their home area are choosing to buy a new bike compared to the same motor used in spite of their usefulness. Meanwhile, the irony is that a new motor that will not last long because it will be sold when they run out of money, so practical just to show off the course. On the other hand, it is also said to be a state of hyperreality.

Public perception of Women Migrant Workers from Taiwan and Hong Kong after the after-work and return to their home area is in line with the opinion Wertheim, which states that a very important change is happening now is the depletion of the difference between the traditional era and modern era [20]. Physical isolation and socio-cultural that used to create the conditions for strong traditionalist roots in village life is increasingly reduced and even disappear. With more and more open to outside influences both regionally, nationally and internationally. Influences that covers various aspects especially the sociocultural and economic. With the growing role of the modern capitalist system shown by sains- technology at the core of the globalization process, economic aspects has become the strength of a very large effect on the process of change. These changes have also created the differentiation-differentiation among the community.

Second, status not married or single carried by women migrant workers. In general, symbolic of young children or who are still single is freedom. It was not without reason, usually said to be like that because they still do not have a "bond" in an organization of "marriage". Therefore, what they do indeed tend to be more "free" than are married. "Freedom" was also evident from the way they do in consumption in accordance with their wishes. Goods they consume too smelly "symbolic" for example buy a new motor with a reason to look more "slang". Often they fall into a situation that hyper reality as always pursue the "symbol" individual to where they are recognized. Moreover, with the development of technology such as this, thus simulating the influence they can come from anywhere, either from the real world and the virtual world. Meaning "young" attached to make their behavior will be "free" and "off" no load.

This shows that Migrants Women from Taiwan and Hong Kong after the after-work and return to their home area who are single interpret the change means "a process that resulted in the present situation is different from the previous state, the change could be a setback and could also be the progress" (Syani) [21].

Next, the third was to look different with the whole village community. They want to be better because it has a lot of money and can afford to buy what they want. In addition, the "sense of pride" also affects their orientation in spending anything. Actually, the "sense of pride" as well as symbolic value prevailing in the society. For example, about something that is valued "more" by the community then it will be endeavored to have such a new motor. So what they are buying not because of its usefulness, but because they want to gain prestige. Such a state is a reflection of "simulacra" as a sign attached to the commodity is beyond the reality of. Therefore, their behavior has been hyper reality because only the pursuit of something that is not real.

From the research that has been done, there is a fact that consumer behavior conducted on migrant women affected by the hegemony, i.e. the perception of and inside of female migrant workers themselves. Perception of the community was also influenced by the experiences of the past, by habit or culture. Most of them think that women migrant workers was definitely luck and success. In addition, they also assume that success is manifested in something that looks, which is likely to be valuable commercially. Actually communities have hegemony by the criteria of "successful a woman migrant worker, so that they value to determine the success or failure of someone from what he had.

The phenomenon of research such a community perception that unconsciously has also hegemony of Female Migrant Workers from Taiwan and Hong Kong after retirement and return to their area of origin to behave consumptively. What they do in order to be seen as successful by the surrounding community, while the criteria for success are determined by the things they own. Consumption of electronic goods, motor vehicles, and cosmetics are actually also due to the hegemony of public perception. Female Migrant Workers from Taiwan and Hong Kong after retiring and returning to their hometown will follow the path determined by the surrounding community, what they consume always refers to the opinions of the community. As a result of this according to Ritzer, changes that occur in one section will bring changes in other parts, it is because the social system basically consists of interrelated elements and contribute to each other in creating balance [8]. 
In addition, the consumptive behavior of female migrant workers from Taiwan and Hong Kong after retirement and returning to their hometowns is also a result of being hegemony by their own minds who want to look different from the general population because of their status as female migrant workers. The existence of such thoughts is very influential on the behavior they show. For example, the reason they buy a motorcycle with cash is to make it look different from the people who usually only buy with credit. Buying a motorbike in cash in the village is only done by those who are capable, so that if women migrant workers from Taiwan and Hong Kong after retirement and return to their area of origin can do that indirectly being "above" the community at large.

From the above explanation, it can be concluded that the change in behavior carried out by Female Migrant Workers from Taiwan and Hong Kong after retiring and returning to their area of origin due to the hegemony both from the people's perception and from their own minds who want to look different from the community. The existence of community perceptions about the success criteria of a Female Migrant Worker from Taiwan and Hong Kong after retiring and returning to their area of origin indirectly makes the female migrant worker follow that perception. What they consume is something that is considered more valuable by the community, so that it can be said to be successful by the surrounding community. Meanwhile, the change in appearance made by female migrant workers was due to "hegemony" by their own thoughts that wanted to look different from the village community. They want to show their existence as female migrant workers who have gone abroad and have a lot of money. Furthermore, the performances they show are also inseparable from the "imaging" of beautiful meanings by the media both electronic and mass media, so that many of them "equate" their appearance with artists who are in adverts.

This above is in line with This perspective is focused on functional requirements or requirements that must be met by a social system in sustaining life and structures appropriate to meet those needs. In accordance with this view, the social system has a tendency to perform certain functions necessary for the survival of a social system. Therefore the sociological analysis seeks to examine the social structures that implement the functionality to meet the needs of the social system [22]

\subsection{Internal and external factors that encourage Women Migrant Workers change of Taiwan and Hong Kong after the after-work and return to their home area}

\subsubsection{Internal Factors}

\subsubsection{Motivation}

The phenomenon of the field indicate the motivation for someone to be a female migrant worker primary purpose is to improve the quality of life in the future, this is in accordance with the Griffin, states that motivation is a set factors that cause people to behave a certain way performance [9]. In a more general sense Hoy and Miskel says that motivation refers to the process of making choices among various forms of voluntary activities of a person [10].

The easy information in the departure of the most important motivation is the existence of ever-increasing needs of life. This shows that there is an impulse that causes a person to try to achieve goals, both consciously and unconsciously. Encouragement also causes a person to behave that can control and maintain his activities. This is in line with Hoy \& Miskel explains that the conditions, needs (desires), desires (desires), and expectations (expectancies) leads to behavior. If this is not fulfilled, it will cause disequilibrium in a person, so that the person concerned will renew the way to reduce the imbalance through certain behaviors or actions or vice versa [10]. If the needs, desires, motives, and expectations are fulfilled it will perfect the balance again. In other words, if someone's goals have been achieved will provide feedback to someone.

Many factors are pushing the peoples of the informants to be migrant workers, especially women Capping Village community, the majority of economic factors. The desire to be able to improve the economy of the family who became their main reasons. Not only the economy there are some other things also encourages them to become migrant women. Another factor that drives and influences to become migrant women are as follows:

a. economic factors

There are many statements about the economic factors. First, they want to have a salary (compensation) is high with their low level of education (among graduates of junior high and high school). Second, add the savings to start a business in Indonesia later. Third, eager to have a decent home, because some migrant workers who have long been working there to improve their living standards one of the proof by building decent housing can even be quite luxurious.

b. Looking for work experience

Most migrant women are also not only make the job as levers of their economies but also to add and look for work experience. This is proven by the one of the informants who become migrant women when they are no longer young age or in their productive age. Evidenced also by their working years is not too long, only about 3- 5 years.

c. Family

Not a few people chose to be migrant women with a basic impulse of the family, or even instructed by her parents who had first become migrant women. When the researchers did a little digging no data that informants in a family which includes nearly $80 \%$ of its members had been a female migrant workers (there is already the former and still be TKI). Of father, mother, sister, uncle, aunt, even sister in law, etc. It can be said a migrant worker job or profession is a job to the next.

d. The narrowness of the area of work in Indonesia

The lack of employment land is also a driving factor of their desire to be a woman migrant worker. In fact, this is also not something new anymore but it is a disease and the PR government, because of the increase or rising unemployment in 
Indonesia from year to year. Rising unemployment proves that land a job in Indonesia is extremely tight, especially for people who have minimal education and it makes people to look for work in another country in spite of the risks of various kinds. Land a job that feels cramped for society due to factors that minimal education and lack of socialization on the importance of education factors and opportunities for entrepreneurship.

\subsubsection{Perception Women Migrant Workers from Taiwan and Hong Kong after the after-work and return to their home area}

Their perception of work as migrant women abroad bring about change for themselves and their families, which changes the perceived is the rising economic level with a proven their ability to buy luxury goods and building houses an internal factors that cause a woman to become migrant women in overseas.

Perception that being female migrant workers they will be able to send money for subsistence, namely for the daily food and clothing indicates his or her family earned income is higher than income jobs in the area of origin. This is in line with the opinion of conceptualizing Parsons ideal society in which cultural values institutionalized in social systems and norms are internalized in the personality system. Then, according to this view individuals will obey social expectations-expectations as regards the regulation is valid (considering the source) and because the regulations consistent with their own values are internalized it. As well as resulting from the orientation of shared values, norms have aligned characters, thus competing expectations will not plunge the individual into the inner conflict. The individual is the main function in the social [8].

The phenomenon of society appreciating (praising) its presence thanks to the ability on an economy of scale as evidenced by the availability of new equipment and being able to build a better house than before also leads to changes in existing social behavior where Burhan Bungin (1994: 123) says social change is a social process experienced by members of the community as well as all elements of culture and social systems, where all levels of community life are voluntarily or influenced by elements of adjusting themselves and using new patterns of life, culture, and social systems [23].

\subsubsection{External Factors}

Externally External drives Social Behavior changes indicated by the Migrant Women Workers from Taiwan and Hong Kong after the after-work and return to their home area of origin is explained by

\subsubsection{Reference Group}

Derived from the reference group fellow migrant women who give direct effect are those that interact, these effects may expose migrant women towards lifestyle and certain behavioral phenomenon is in line with the proposed Himes and Moore there are three kinds in the dimension of social change, namely, the dimension structural, cultural, and in the dimension of interactional. In the dimension of structurally refers to changes form the structure of society, changes in the role, the emergence of a new role.

Their reference group referenced the migrant workers this woman could be considered to stand out in the lifestyle shift that hit the Indonesian Manpower is a lifestyle that they generally tend to be influenced by advances in technology and western style is also in line with the opinions expressed Ogburn (in Ridwan 1998 case: 58) that changes in technology lead to material changes in the environment, causing changes or modifications occur habits common prevalence in the community and in social institutions. In the cultural, material and non-material aspect is a factor that is always involved.

\subsubsection{Family}

The women depart to become female migrant workers with careful consideration of the condition of their families going forward by trying opportunities to work abroad, in addition to departing to become female migrant workers because they want to improve family life from the encouragement of families who have been female migrant workers before even without a diploma and adequate achievement. Someone can choose his life path and in the process of choosing it, depending on how the character and knowledge of each individual about something received from the results of the socialization. In Coleman's rational choice theory, there are two main elements namely actors and resources. These resources are those that can be controlled by the actor. The actors referred to in this study were female workers in the Pagu. According to Coleman (in Ritzer) that is a rational choice theory, not too focused on what is the choice or what is the choice of actors, the important thing is that the action is carried out in order to achieve a goal in accordance with the choice of actors [24].

\subsubsection{Social Class}

The results showed female workers abroad can support and enhance the social class and the dignity of self and family, this is in accordance with the opinion Ritzer changes in one part will bring changes to another part, it is because the social system in essentially consists of elements that are interrelated and contribute in creating a balance [8].

Table 1. Social Behavior changes indicated by the Migrant Women Workers from Taiwan and Hong Kong Before and After the after-work 
International Journal of Advances in Scientific Research and Engineering (ijasre), Vol 6 (4), April -2020

\begin{tabular}{|c|c|c|}
\hline Change & $\begin{array}{c}\text { Prior to becoming Women Migrant } \\
\text { Workers }\end{array}$ & After Being Migrant Workers \\
\hline $\begin{array}{l}\text { consumption } \\
\text { behavior }\end{array}$ & $\begin{array}{l}\text { 1. Consumption there is a tendency } \\
\text { tailored to the needs of limited desire } \\
\text { for goods desired consumption } \\
\text { 2. Consumption of goods made only } \\
\text { limited fulfillment of demands }\end{array}$ & $\begin{array}{l}\text { 1. Consumption turns into consumerism does not } \\
\text { suit the needs of existing excess consumption } \\
\text { trends to meet the desires that previously could } \\
\text { not be embodied } \\
\text { 2. Consumption goods that do tend to show the } \\
\text { prestige of his success working abroad }\end{array}$ \\
\hline Social behavior & $\begin{array}{l}\text { 3. Behave like innocent villagers in } \\
\text { general } \\
\text { 4. Easily adapt to their social } \\
\text { environment } \\
\text { 5. Communicate like other residents }\end{array}$ & $\begin{array}{l}\text { 3. Social behavior changed impressed bring the } \\
\text { existing behavior in which he worked } \\
\text { 4. behavior that is where he works seem more self- } \\
\text { limiting and feel has been more successful in the } \\
\text { appeal are not migrant workers } \\
\text { 5. Tend to be more closed and only communicate } \\
\text { with their fellow migrant workers first place he } \\
\text { worked }\end{array}$ \\
\hline $\begin{array}{l}\text { Public } \\
\text { perception }\end{array}$ & $\begin{array}{l}\text { 6. Perceived as ordinary citizens who } \\
\text { have limited economic }\end{array}$ & 6. Perceived as successful citizens working abroad \\
\hline
\end{tabular}

\section{CONCLUSION}

From the above it can be concluded that:

1) Women Migrant Workers from Taiwan and Hong Kong after the after-work and return to their hometown to become more consumptive due to different expectations and reality after following the trend of lifestyle is no longer based on the value of the goods it consumes

2) Behavior Change Social Life Women Migrant Workers from Taiwan and Hong Kong after the after-work and return to their home area caused by environmental factors, the adjustment to the work environment, long working life and lack of communication.

3) Public perception of the success Women Migrant Workers from Taiwan and Hong Kong after the after-work and return to their home area Migrants become hegemony makes it follows that perception.

4) Internal and external factors that encourage Social behavior indicated by the Migrant Women Workers from Taiwan and Hong Kong after the after-work and return to their home area of origin include:

a. Internal:

(1) Motivation of female migrant workers to work abroad is to meet the needs, following in the footsteps of successful female migrant workers previously and lack of employment opportunities in the country

(2) Being perception of women migrant workers abroad brought about changes rising economic level as well as the appreciation of the Society

b. external:

(1) Reference group derived from a fellow migrant women tend to be influenced by advances in technology and style of the West

(2) Fixing Family Life and thrust another successful Family Members become migrant women is the goal of becoming migrant women Women Abroad

(3) Working Abroad considered increase social class and dignity themselves and their families better.

\section{RESEARCH RECOMMENDATIONS}

\subsection{Theoretical implications}

In this study examines the problem of social attitudes shown by Former Migrant Worker Women From Taiwan and Hong Kong, which has been Full Working with major theories (grand theory), the theory Struktutal Functional of Talcot Parsons, 1991 which says: The social behavior of a person that appears in the pattern responses among those represented by the interrelationships between individuals. Social behavior is also identical to the person's reaction to another person so that the theoretical implications of this study is to support the role of behavior theory Talcott Parsons, where the phenomenon of Social Behaviorshown by Ex Women Migrant Workers From Taiwan and Hong Kong who has been Full Employment in the District Capping village Wates Kediri, which leads to equilibrium, in the form of structural adjustments and functional to maintain its existence. It demonstrated the social behavior of former migrant workers returning from abroad after it appeared in 
response to economic conditions who were not able to be someone who is now able to get it. Social behavior is also identical to the person's reaction to others where Social Behaviorshown by Ex Women Migrant Workers From Taiwan and Hong Kong who has been impressed Full Work less socializing with the environment and tend to shut down due to behavioral habits acquired when working out.

It is in line with the theory of voluntaristic Prasons where there are three aspects of human action that is the agent unit (perpetrator) is trying to realize its objectives in a situation when the material conditions and the way a manner that allows use to realize the goals. Where phenomenon suggests that women migrant workers have worked to realize the desire of improving the lives of the previous one. Parsons believes that social norms are internalized during socialization process of forming an alternative base action on what is offered individual desires.

\subsection{Practical implications}

In accordance with the research findings, makaada some suggestions that can be a practical contribution in this research is as follows:

a. In anticipation of consumer behavior Social Behavior exhibited by Former Migrant Worker Women From Taiwan and Hong Kong, which has been Full Working before leaving abroad so what is aspired to dicapai.pulang related agencies should firstly need to establish their point of view.

b. To minimize Change Social Behavior exhibited by Former Migrant Worker Women From Taiwan and Hong Kong that Had Full Employment caused by environmental factors, the adjustment to the work environment, long working life and lack of communication with the involvement of the village so they could behave appropriately and remind that Being TKI is not a guarantee to change their lives for the better, for it to be better it all depends on individuals who live it. Because every human life at risk and respective exam but not all people can confront and apply prudent in mengahadapinya.

c. To the government to be trying even harder to overcome the problem of employment opportunities and pay more attention to the little people whose income is low so our nation can continue to live independently is not dependent on other countries to do:

1) the government continues to boost the quality of our workforce, the quality of our human resources through education and vocational training in order to prevail in their own country.

2) The government should pay more attention to the conditions of migrant workers abroad, including those facing the death penalty abroad.

3) Should coordinate with the recruitment agency to strengthen the commitment of women migrant workers before they go abroad in order to minimize changes in the behavior of women migrant workers.

\section{REFERENCES}

1. Ibrahim Rusli, 2001. Promosi Kesehatan Dengan Pendekatan Teori Prilaku, Media, Dan Aplikasinya. Semarang: PT. Raja Grafindo Persada.

2. Kotler, Philip. 2002. Manajemen Pemasaran, Edisi Millenium, Jilid 2, PT Prenhallindo, Jakarta.

3. Mowen, C. John dan Michael Minor. 2002. Perilaku Konsumen. Jakarta. Erlangga

4. Rianto, Nur. 2012. Dasar-dasar Pemasaran Lembaga Keuangan. Syariah. Bandung: Alfabeta.

5. Rahardjo.1999. Pengantar Sosiologi Perdesaan dan Pertanian. Yogyakarta : Gadjah Mada University Press.

6. Soekanto, Soerjono. 1983. Sosiologi suara pengantar, Raja Grafindo persada

7. Wirawan, I.B. 2012. Teori Sosial dalam Tiga Paradigma, Fakta Sosial, Definisi Sosial, Perilaku Sosial. Jakarta, Kencana Premada Media Group.

8. Ritzer, George and Douglas J. Goodman, 2008, Teori sosiologi dari sosiologi klasik sapai perkembangan mutakhir teori social post modern, Kreasi wacana, Yogyakarta

9. Griffin, Ricky, 2004. Management, Edisi Ketujuh, jilid 1, Erlangga, Jakarta.

10. Hoy, W.K., \& Miskel, C.G. 1987. Educational Administration: Theory, Research, and Practice. New York: Random House, Inc.

11. Robbins, Stephen dan Coulter, Mary, 2002, Manajemen, Jakarta: Gramedia

12. Moleong, Lexy J. 2010. Metodologi Penelitian Kualitatif, Bandung: Remaja Rosda Karya.

13. Herdiansyah, Haris. 2010. Metode Penelitian Kualitatif untuk Ilmu-ilmu Sosial. Jakarta: Salemba Humanika.

14. Sumartono. 2002. Terperangkap dalam Iklan : Meneropong Imbas Pesan Iklan. Televisi. Bandung: Penerbit Alfabeta 
International Journal of Advances in Scientific Research and Engineering (ijasre), Vol 6 (4), April -2020

15. Engel, J.F., Blackwell, R.D. and Miniard, P.W. 1995. Consumer Behavior, 8th d, Orlando: The Dryden Press.

16. Mowen. 1995. Perilaku Konsumen. Pustaka Ilmu : Jakarta. Ohanian.

17. Chaney, David. 2003. Lifestyles: Sebuah Pengantar Komprehensif. Yogyakarta. Jalasutra.

18. Storey, John. 2009. Cultural Theory and Popular Culture : An Introduction. 5th Edition. Inggris: Pearson Longman.

19. Purnomo, Hari, 2004, Perencanaan dan Perancangan Fasilitas, Edisi Pertama, Yogyakarta: Graha Ilmu.

20. Wertheim, W.F. 1999. Masyarakat Indonesia Dalam Transisi; Studi Perubahan Sosial. Yogyakarta: Tiara Wacana.

21. Syani, Abdul. 1995. Sosiologi dan Perubahan Masyarakat. Pustaka Jaya. Unila. Bandar lampung.

22. Merton. Robert K. 1949/1968. Sosial Theory And Sosial Structure. New York: free press.

23. Bungin, Burhan. 2008. Sosiologi Komunikasi: Teori, Paradigma dan Teknologi Komunikasi di Masyarakat. Kencana. Jakarta.

24. Ritzer, George. 2012. Teori Sosiologi. Yogyakarta : Pustaka Pelajar. 